\title{
Desain Antena Mikrostrip Rectangular Patch Array $1 \times 2$ dengan U-Slot Frekuensi 28 GHz
}

\author{
FAJAR WAHYU ARDIANTO, SETYAWAN RENALDY, FARHAN FATHIR \\ LANANG, TRASMA YUNITA
}

\author{
S1 Teknik Telekomunikasi Fakultas Teknik Elektro Universitas Telkom \\ Email: fajarwahyuar7@gmail.com
}

Received 30 April 2018 | Revised 2 Juni 2018 | Accepted 8 November 2018

\begin{abstract}
ABSTRAK
Kebutuhan pengguna yang semakin meningkat harus diimbangi dengan peningkatan kecepatan data dan kapasitas suatu jaringan, sehingga diperlukan bandwidth yang lebar. $5 G$ merupakan salah satu teknologi yang akan diresmikan tahun 2020 yang menjadi solusi terhadap peningkatan kecepatan data dan kapasitas layanan. Salah satu kandidat yang menjadi frekuensi kerja $5 G$ yaitu 28 $\mathrm{GHz}$. Antena mikrostrip merupakan salah satu jenis antena yang dapat digunakan untuk teknologi 5G. Namun, antena mikrostrip memiliki beberapa kekurangan, diantaranya bandwidth dan gain yang kecil. Untuk itu, dibutuhkan teknik yang dapat meningkatkan bandwidth dan gain antena. Pada penelitian ini dirancang antena mikrostrip bentuk rectangular patch yang ditambahkan slot berbentuk $U$ dengan tujuan meningkatkan bandwidth dan disusun secara array $1 \times 2$ untuk meningkatkan gain antena. Hasil dari simulasi didapatkan antena mampu bekerja pada rentang frekuensi $27,5 \mathrm{GHz}-29,12 \mathrm{GHz}$ pada batas return loss kurang dari -15 dB dengan bandwidth sebesar 1,62 GHz. Nilai gain yang dihasilkan sebesar 7,52 dB. Pola radiasi yang dihasilkan, yaitu unidireksional dan berpolarisasi secara linear.
\end{abstract}

Kata kunci: 5G, $28 \mathrm{GHz}$, mikrostrip, rectangular patch, array, U-Slot

\begin{abstract}
Data rate and network capacity improvements offset the increase of user needs, hence it requires a wider bandwidth. The most current high-end technology, which can solve the problem is $5 G$. One of the frequency that becomes the candidate of $5 G$ is $28 \mathrm{GHz}$. For 5G, it could apply one of the antenna types, micro strip antenna. However, micro strip antenna has a shortage of narrow bandwidth and small gain. Therefore, it requires a technique to increase the bandwidth and gain of the antenna. In this study, the form of micro strip of antenna design is a rectangular patch with the addition of U-Slot and arranged $1 \times 2$ to increase the bandwidth and antenna gain. The results of the simulation show that the antenna is working well at the range frequency of $27.5 \mathrm{GHz}-29.12 \mathrm{GHz}$, with a return loss limit of $-15 \mathrm{~dB}$ with bandwidth of $1.62 \mathrm{GHz}$, the resulting gain value is $7.52 \mathrm{~dB}$, the resulting radiation pattern is unidirectional and linearly polarized.
\end{abstract}

Keywords: 5G, $28 \mathrm{GHz}$, microstrip, rectangular patch, array, U-Slot 


\section{PENDAHULUAN}

Perkembangan teknologi di dunia khususnya pada bidang telekomunikasi sangatlah cepat. Hal ini sebanding dengan kebutuhan pengguna perangkat mobile seperti smartphone yang setiap tahunnya mengalami peningkatan. Pengguna selalu menginginkan untuk mendapatkan akses pertukaran informasi yang sangat cepat dan mampu melayani kebutuhan akses data tanpa adanya delay. Maka dari itu, dibutuhkan kapasitas jaringan dan lebar pita yang lebih besar dibandingkan dengan teknologi saat ini (Ardianto, Adriansyah, \& Syihabuddin, 2018). Selain itu, perkembangan teknologi memungkinkan perangkat pengguna baik yang mobile maupun fixed untuk bisa saling terkoneksi satu sama lain dengan delay yang sangat kecil. Hal inikarena tidak ada sistem tanpa delay. Sebagai contoh di 5G untuk Ultra Reliable and Low Latency (URLL) mensyaratkan latency atau delay kurang dari $1 \mathrm{~ms}$ untuk mobil self driving, robot sugery, dll. Teknologi telekomunikasi generasi kelima atau 5G sebagai penerus 4G diharapkan mampu menjawab tantangan permintaan kapasitas dan data rate yang tinggi serta dapat mengurangi delay. Pada saat ini, teknologi 5G masih belum memiliki standardisasi yang mengatur secara baku penerapan dari teknologi tersebut (5G Americas White Paper on 5G Spectrum Recomendations, 2017). Semua operator berlomba-lomba dan bahkan sudah mulai komersialisasi, kemungkinan 2019 sudah mulai banyak komersialisasinya.

Telah banyak inovasi yang ditawarkan untuk dapat dijadikan teknologi pendukung komunikasi 5G. Penggunaan gelombang yang bekerja di atas frekuensi $6 \mathrm{GHz}$ menjadi salah satu arah pengembangan teknologi 5G. Sudah banyak alokasi frekuensi yang ditawarkan menjadi frekuensi utama komunikasi 5G. Para peneliti telah memberikan beberapa usulan kandidat frekuensi yang dijadikan sebagai frekuensi utama pada 5G, yaitu $15 \mathrm{GHz}$ (Tateishi, et al., 2017), $28 \mathrm{GHz}$ dan $38 \mathrm{GHz}$ (Qamar, Siddiqui, Dimyati, Noordin, \& Majed, 2017). Salah satu kandidat frekuensi $5 \mathrm{G}$ yang telah banyak dilakukan penelitian, yaitu frekuensi $28 \mathrm{GHz}$. Hal ini juga diusulkan oleh Federal Communications Commission (FCC) yang mengusulkan frekuensi kerja teknologi $5 \mathrm{G}$ pada frekuensi $28 \mathrm{GHz}$ dengan rentang frekuensi $27,5 \mathrm{GHz}-29,5$ GHz (5G Americas White Paper on 5G Spectrum Recomendations, 2017).

Pada sistem telekomunikasi selular, antena merupakan salah satu komponen yang sangat penting. Penggunaan frekuensi tinggi dapat menyebabkan dimensi suatu antena mengecil, sehingga teknologi $5 \mathrm{G}$ membutuhkan antena yang mudah untuk diintegrasikan. Salah satu jenis antena yang cocok untuk menjadi kandidat teknologi $5 G$, yaitu antena mikrostrip. Antena mikrostrip memiliki ukuran yang, tipis, kecil, mudah diintegrasikan dan dapat beroprasi pada frekuensi tinggi. Namun, antena mikrotsrip mempunyai kekurangan, yaitu bandwidth yang sempit (Balanis, 2005), sehingga dibutuhkan teknik khusus untuk dapat meningkatkan bandwidth antena mikrostrip. Selain itu, antena mikrostrip menghasilkan gain yang kecil, sehingga diperlukan teknik penyusunan antena secara array. Penyusunan antena secara array dapat meningkatkan gain dan direktivitas dari suatu antena (Balanis, 2005), sehingga arah pancar antena menjadi lebih terarah. Hal ini sangat diperlukan pada teknologi 5G (Hakimi \& Rahim, 2014).

Salah satu teknik untuk meningkatkan bandwidth antena dengan menggunakan penambahan slot pada patch antena. Pada tahun 2015, penelitian yang telah dilakukan oleh Firmansyah (Firmansyah, Purnomo, Fatonah, \& Nugroho, 2015) dan timnya, telah melakukan analisis pengujian antena mikrostrip yang menggunakan rectangular patch hanya mampu menghasilkan bandwidth sebesar $100 \mathrm{MHz}$. Pada tahun 2017, penelitian yang dilakukan oleh Kevin (Sinaga, Nur, \& Syihabuddin, 2017) dan timnya, telah dilakukan penelitian mengenai penggunaan U-Slot pada rectangular patch dapat meningkatkan bandwidth antena sebesar $400 \mathrm{MHz}$. Namun, antena yang dianalisis bekerja pada frekuensi $15 \mathrm{GHz}$. Untuk sistem 
komunikasi $5 \mathrm{G}$ pada frekuensi $28 \mathrm{GHz}$, dirancang antena Bent Line Grid Array yang memiliki bandwidth sesuai dengan standar FCC, tetapi antena tersebut memiliki bentuk yang rumit (Hakimi \& Rahim, 2014). Pada penelitian ini dirancang antena mikrostrip dengan bentuk rectangular patch yang ditambahkan U-slot pada bagian patch-nya dengan tujuan untuk meningkatkan bandwidth antena dan mampu bekerja pada frekuensi $28 \mathrm{GHz}$, kemudian disusun secara array $1 \times 2$ untuk meningkatkan gain antena. Selain itu, antena yang dirancang memiliki pola radiasi unidireksional dan berpolarisasi secara linear. Sehingga, dengan demikian antena digunakan untuk kepentingan komunikasi pada teknologi 5G.

\section{METODOLOGI PENELITIAN}

\subsection{Antena Mikrostrip Rectangular Patch}

Gambar 1 menunjukkan gambaran bentuk antena mikrostrip rectangular patch yang tersusun atas tiga bagian.

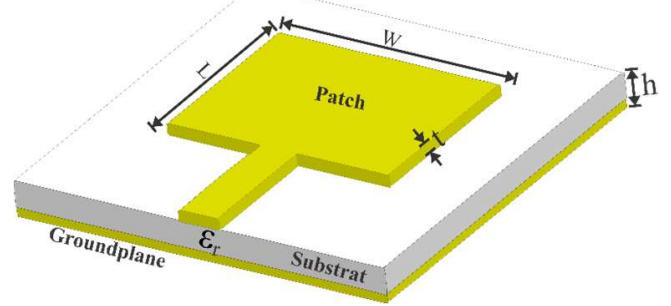

Gambar 1. Antena Mikrostrip Rectangular Patch.

Menurut Institute of Electrical and Electronics Engineers (IEEE), antena diartikan sebagai sebuah alat yang mampu memancarkan dan menerima gelombang elektromagnetik (Balanis, 2005). Secara umum, antena memiliki fungsi sebagai transducer dari gelombang listrik menjadi gelombang elektromagnetik atau sebaliknya. Salah satu jenis antena yang dapat digunakan adalah antena mikrostrip. Antena mikrostrip memiliki susunan yang terdiri dari groundplane sebagai reflektor gelombang elektromagnetik, substrat yang berisi bahan dielektrik sebagai penyalur gelombang elektromagnetik dan patch sebagai elemen peradiasi (Balanis, 2005). Antena mikrostrip bentuk rectangular patch merupakan bentuk patch yang paling banyak digunakan, karena memiliki bentuk yang sederhana. Secara umum, perhitungan dimensi rectangular patch seperti yang ditunjukkan pada Persamaan (1) sampai (4) (Balanis, 2005),

$$
\begin{aligned}
& \varepsilon_{e f f}=\frac{\varepsilon_{r}+1}{2}+\frac{\varepsilon_{r}-1}{2}\left(1+12 \frac{h}{W}\right)^{-\frac{1}{2}}, \\
& \Delta L=0,412 h\left(\frac{\varepsilon_{e f f}+0,3}{\varepsilon_{e f f}-0,258}\right)\left(\frac{\frac{W}{h}+0,264}{\frac{W}{h}-0,8}\right), \\
& L=\frac{c}{2 f \sqrt{\varepsilon_{e f f}}}-2 \Delta L, \\
& W=\frac{c}{2 f}\left(\frac{\varepsilon_{r}+1}{2}\right)^{-\frac{1}{2}},
\end{aligned}
$$

dengan $L$ merupakan panjang dari patch $(m)$ dan $W$ merupakan lebar dari patch $(m), f$ merupakan frekuensi resonansi yang digunakan, $c$ merupakan kecepatan cahaya pada ruang hampa $\left(3 \times 10^{8} \mathrm{~m} / \mathrm{s}\right), \varepsilon_{r}$ merupakan permitivitas relatif suatu bahan, $\varepsilon_{\text {eff }}$ merupakan 
permitivitas efektif konstan dan $h$ merupakan ketebalan dari bahan substrat. $\Delta L$ merupakan pertambahan panjang dari $L$ yang terjadi karena oleh fringing effect.

\subsection{Array Antena}

Pada umumnya antena dengan satu elemen patch menghasilkan gain yang rendah, sehingga pola radiasi antena yang dihasilkan melebar. Beberapa aplikasi perlu mendesain antena dengan karakteristik yang memiliki directivity tinggi. Hal ini bertujuan untuk memenuhi kebutuhan komunikasi jarak jauh. Walaupun hal ini dapat dicapai dengan cara memperbesar dimensi suatu antena, sehingga ukuran antena menjadi lebih besar (Balanis, 2005).

Memperbesar dimensi elemen tunggal antena dapat menghasilkan direktivitas menjadi lebih terarah. Cara lain untuk memperbesar dimensi antena tanpa harus meningkatkan ukuran elemen-elemen tunggal adalah membentuk antena menjadi susunan array. Dalam implementasinya, elemen-elemen pada antena array adalah identik. Selain menghasilkan direktivitas yang tinggi, array juga dapat meningkatkan nilai gain maksimum suatu antena. Semakin tinggi gain suatu antena, maka direktivitas antena menjadi lebih besar atau terarah, sedangkan pola radiasinya cenderung menyempit sehingga menyebabkan nilai beamwidth menjadi kecil (Balanis, 2005). Gambar 2 menggambarkan antena yang disusun secara array $1 \times 2$ dengan menggunakan patch berbentuk rectangular.

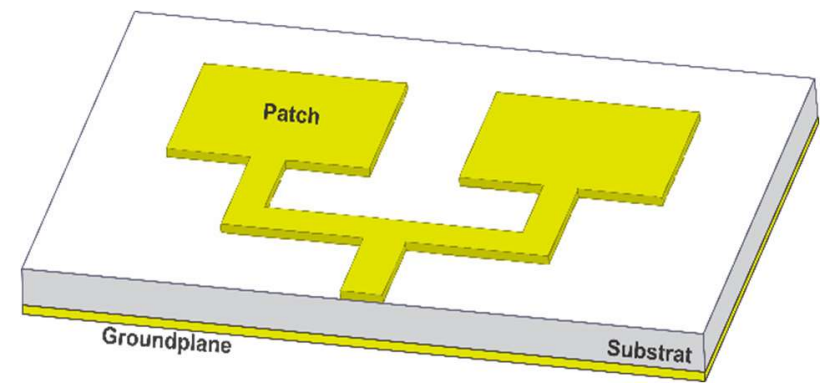

Gambar 2. Antena Susunan Array.

\subsection{Metode U-Slot}

Antena mikrostrip memiliki kekurangan dalam hal bandwidth. Salah satunya, bandwidth yang sempit. Salah satu teknik yang digunakan untuk memperbesar bandwidth antena mikrostrip adalah dengan melakukan penambahan slot pada patch antena. Slot antena dapat memiliki bentuk yang beragam seperti $U, H, T, E$ dan V. Penelitian (Ather \& Singhal, 2013) menunjukkan bahwa dengan penambahan U-Slot dapat meningkatkan bandwidth sebesar $50,7 \%$, sedangkan penambahan $\mathrm{H}$-Slot hanya dapat meningkatkan bandwidth sebesar $21,2 \%$. Penambahan slot yang berbentuk huruf $U$ memiliki bentuk yang sederhana dan telah terbukti pada penelitian sebelumnya dapat meningkatkan bandwidth antena (Sinaga, Nur, \& Syihabuddin, 2017).

Antena mikrostrip yang telah ditambahkan slotmenyebabkan kopling induktif dihantarkan dari catuan menuju ke slot. Kopling induktif yang semakin besar dapat menyebabkan faktor kualitas antena menjadi berkurang. Penurunan faktor kualitas berdampak pada bandwidth antena menjadi lebih lebar (Balanis, 2005). Perhitungan ukuran-ukuran dari U-Slot, dapat menggunakan Persamaan (5) sampai (7) (Sinaga, Nur, \& Syihabuddin, 2017),

$$
\begin{aligned}
& F=\frac{\lambda}{60}, \\
& \frac{E}{W} \geq 0,3,
\end{aligned}
$$




$$
D=\frac{c}{f_{l o w} \sqrt{\varepsilon_{e f f}}}-2(L+2 \Delta L-F),
$$

Dimana $\lambda$ merupakan panjang gelombang dari frekuensi resonansi, $W$ merupakan lebar patch, $F$ merupakan lebar slot, $E$ merupakan panjang slot secara vertikal, dan $D$ merupakan panjang slot secara horizontal. Gambar 3 menunjukkan gambaran bentuk antena mikrostrip rectangular patch yang telah ditambahkan U-Slot.

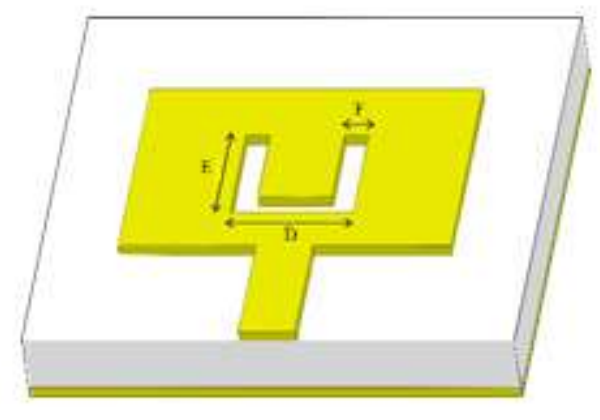

Gambar 3. Dimensi U-Slot.

\subsection{Catuan Antena}

Untuk mencatu energi elektromagnetik dari saluran lossless ke antena, terdapat berbagai macam teknik seperti aperture coupling, coaxial feed, coplanar waveguide dan microstrip feed line. Berbagai macam teknik tersebut memiliki kelebihan dan kekurangan. Teknik catuan yang digunakan bertujuan untuk transfer daya yang efisien antara struktur feeding dengan struktur peradiasi dan impedansi keduanya harus matched.

Pada penelitian ini, catuan menggunakan metode microstrip feed line. Metode tersebut lebih sesuai untuk diterapkan pada perancangan antena yang disusun secara array. Penentuan dimensi lebar $(W f)$ dan panjang $(L f)$ dari microstrip feed line seperti yang ditunjukkan pada Persamaan (8) dan (9) (Balanis, 2005),

$$
\begin{gathered}
W f=\frac{2 h}{\pi}\left\{B-1-\ln (2 B-1)+\frac{\varepsilon_{r}-1}{\varepsilon_{r} 2}\left[\ln (B-1)+0.39-\frac{0.61}{\varepsilon_{r}}\right]\right\}, \\
L f=\frac{\frac{\lambda}{\sqrt{\varepsilon_{e f f}}}}{4},
\end{gathered}
$$

Perhitungan nilai $\mathrm{B}$ dan $Z_{0}$ sebagai impedansi saluran catu seperti yang ditunjukkan pada Persamaan (9) dan (10) (Singh \& Tripathi, 2011),

$$
\begin{gathered}
B=\frac{60 \pi^{2}}{Z_{o} \sqrt{\varepsilon_{r}}}, \\
Z_{0}=\frac{60}{\sqrt{\varepsilon_{\text {eff }}}} \ln \left[\frac{8 h}{W}+\frac{W}{4 h}\right] .
\end{gathered}
$$

Selain itu, antena yang disusun secara array membutuhkan teknik pembagi daya, sehingga arus yang mengalir pada saluran transmisi dapat seimbang. Teknik yang dipakai menggunakan T-junction. Perhitungan dimensi $T$-junction dengan lebarnya $\left(W_{\text {Junction }}\right)$ dapat dihitung seperti Persamaan (12). 


$$
W_{\text {Junction }}=\frac{\lambda}{2}
$$

\subsection{Spesifikasi Antena}

Pada penelitian ini, antena yang dirancang memiliki rentang frekuensi kerja $27,5 \mathrm{GHz}-29,1$ $\mathrm{GHz}$ yang rentang frekuensi tersebut masuk rekomendasi untuk digunakan di Jepang (5G Americas White Paper on 5G Spectrum Recomendations, 2017). Untuk batas nilai return loss yang digunakan adalah $\leq 15 \mathrm{~dB}$ yang berarti daya yang dipantulkan kembali ke sumber sebesar 3,1\% (Ruswanditya, Wijanto, \& Wahyu, 2017). Kemudian untuk nilai gain yang dirancang $\geq 7 \mathrm{~dB}$ (Kakkar, Nirdosh, Tripathy, \& Singh, 2017) . Spesifikasi antena ditunjukkan pada Tabel 1.

Tabel 1. Spesifikasi Antena.

\begin{tabular}{|c|c|}
\hline Parameter & Spesifikasi \\
\hline Frekuensi Tengah & $28 \mathrm{GHz}$ \\
\hline Frekuensi Kerja & $27,5 \mathrm{GHz}-29,1 \mathrm{GHz}$ \\
\hline Return Loss & $\leq 15 \mathrm{~dB}$ \\
\hline Bandwidth & $1,6 \mathrm{GHz}$ \\
\hline Gain & $\geq 7 \mathrm{~dB}$ \\
\hline Pola radiasi & Unidireksional \\
\hline Polarisasi & Linear \\
\hline
\end{tabular}

Rogers RT/duroid 5880 (tm), digunakan sebagai bahan substrat antena. Rogers RT/duroid 5880 mempunyai permitivitas bahan $\left(\varepsilon_{r}\right)$ sebesar 2,2 dengan ketebalan bahan $(h)$ sebesar $1,575 \mathrm{~mm}$. Alasan pemilihan bahan Duroid 5880 dikarenakan bahan ini mampu digunakan untuk menghasilkan bentuk dimensi yang lebih besar dan dapat bekerja di frekuensi tinggi serta memiliki permitivitas bahan yang kecil. Selain itu, bahan yang digunakan untuk groundplane dan patch adalah cooper dengan ketebalan 0,035 mm. Cooper pada umumnya digunakan untuk antena mikrostrip dikarenakan sangat mudah ditemukan dan memiliki konduktivitas yang cukup baik.

\subsection{Perancangan Simulasi}

Pada penelitian Eddy (Wiyanto, Alam, \& Harsono, 2018) dan timnya, dilakukan penelitian tentang antenna mikrostrip array 1x4 diperoleh gain sebesar $9.04 \mathrm{~dB}$. Pada penelitian yang dilakukan oleh Prabhu (Prabhu, Archana, Mercy, \& Sree, 2017) dan timnya, dilakukan penelitian tentang antena array $1 \times 3$ diperoleh gain sebesar $7,8 \mathrm{~dB}$. Pada penelitian Kevin (Sinaga, Nur, \& Syihabuddin, 2017) dan timnya, telah dilakukan penelitian tentang mengenai penggunaan U-Slot pada array $1 \times 2$ rectangular patch diperoleh gain sebesar 9,2 dB. Namun penelitian (Prabhu, Archana, Mercy, \& Sree, 2017) dan (Sinaga, Nur, \& Syihabuddin, 2017) tidak menggunakan frekuensi $28 \mathrm{GHz}$. Pada penelitian ini akan dirancang antena mikrostrip patch berbentuk rectangular dengan tambahan slotted-patch berbentuk huruf $U$ dan disusun secara array $1 \times 2$ yang bentuk dimensi antena tersebut lebih sederhana dibanding antena array $1 \times 3$. Antena didesain untuk kepentingan komunikasi $5 \mathrm{G}$, khususnya pada frekuensi $28 \mathrm{GHz}$.

Adapun tahapan perancangan diawali dengan menentukan spesifikasi dan bentuk dari antena yang akan dirancang. Kemudian, dilakukan perhitungan menggunakan Persamaan-Persamaan yang telah didapat dari berbagai referensi untuk kemudian didesain pada software. Dalam perancangannya, antena didesain terlebih dahulu tanpa penambahan U-slot. Hal ini dilakukan untuk mengetahui perubahan kinerja antena apabila ditambahkan U-slot pada patch antena. Setelah didesain, antena disimulasikan dan ditinjau apakah sudah memenuhi parameter yang 
diinginkan. Parameter yang dilihat pada saat pengujian adalah frekuensi resonansi dari antena, return loss, bandwidth, pola radiasi, gain, dan axial ratio. Parameter tersebut akan diuji terlebih dahulu melalui simulasi. Apabila belum mencapai spesifikasi, maka dilakukan optimisasi atau melakukan perhitungan ulang menggunakan Persamaan (1) sampai (12). Optimasi dilakukan dengan cara memperbesar atau memperkecil dimensi yang telah didapat dari perhitungan.

Gambar 4 menunjukkan diagram alir pengerjaan simulasi dalam merancang antena rectangular patch array $1 \times 2$ yang bekerja pada frekuensi $28 \mathrm{GHz}$. Gambar 5 dan Gambar 6 menunjukkan desain dari antena mikrostrip rectangular patch yang disusun secara array $1 \times 2$ yang tanpa penambahan slot dan dengan penambahan slot, sedangkan untuk dimensi ukuran antena dapat dilihat pada Tabel 2. Dimensi antena tersebut merupakan hasil optimasi dari simulasi sehingga parameter yang didapat menenuhi spesifikasi antena yang diinginkan.
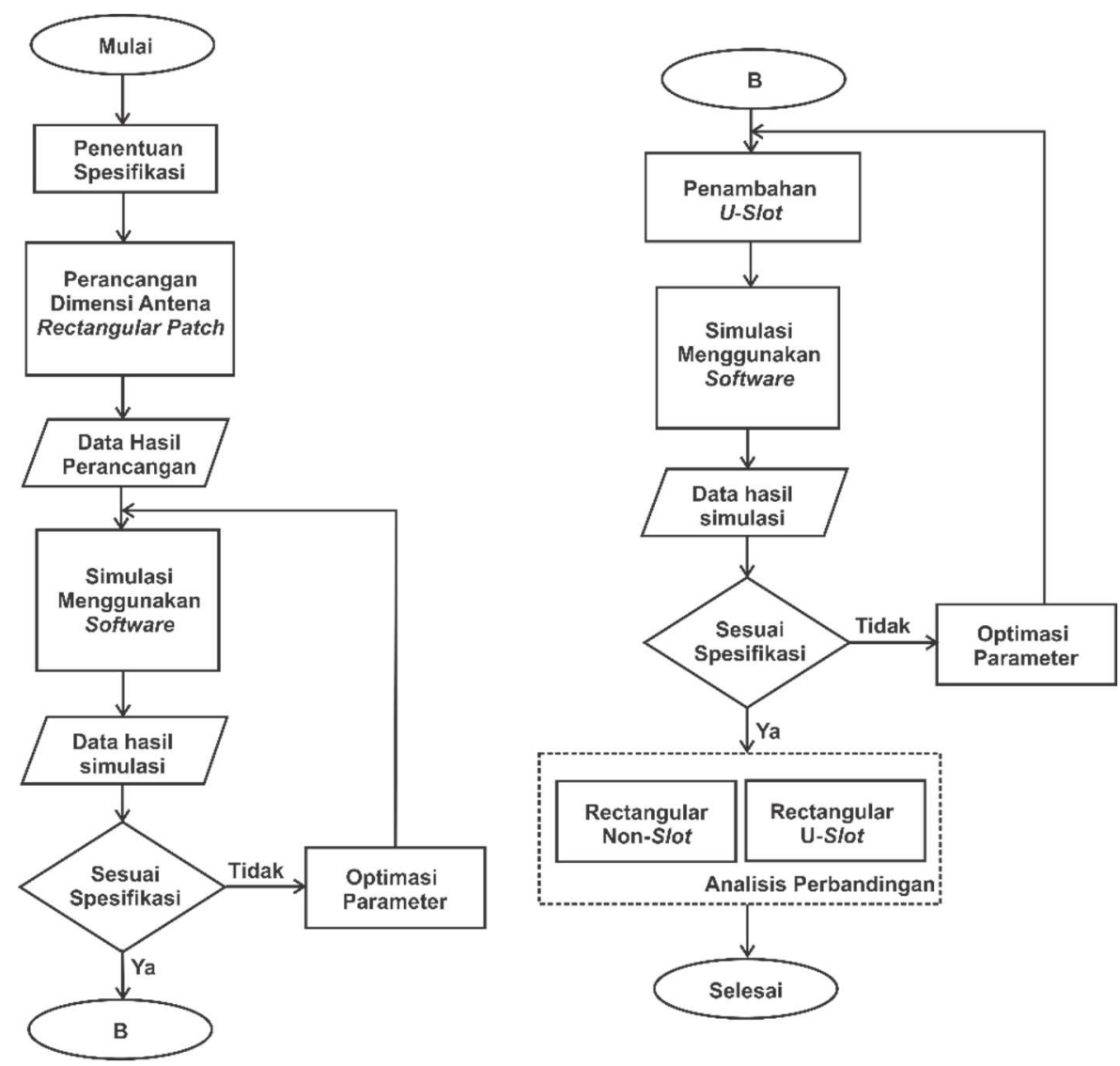

Gambar 4. Diagram Alir Pengerjaan Simulasi. 


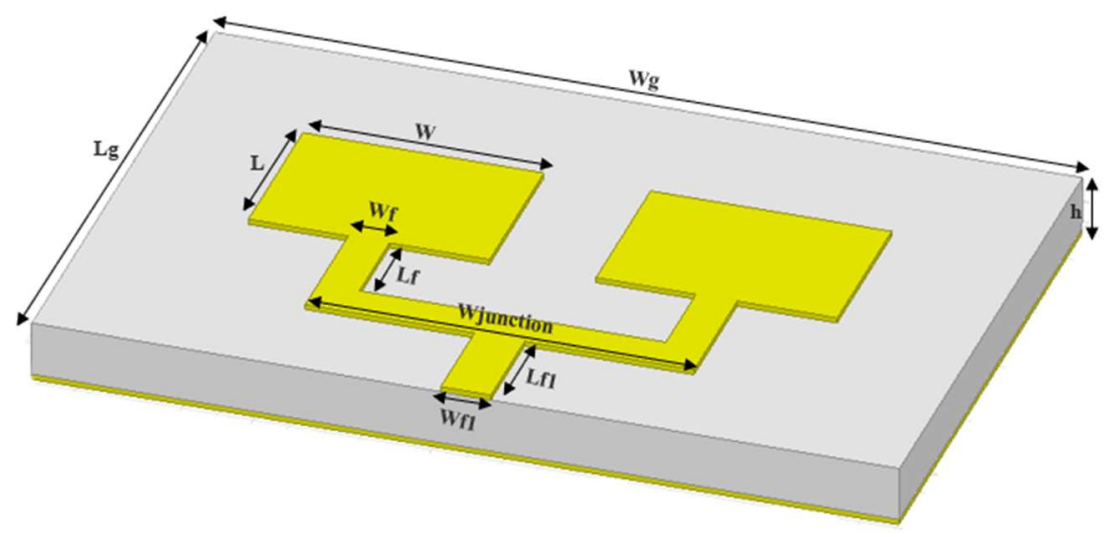

Gambar 5. Desain Antena Mikrostrip Rectangular Patch Array 1x2 Tanpa Slot.

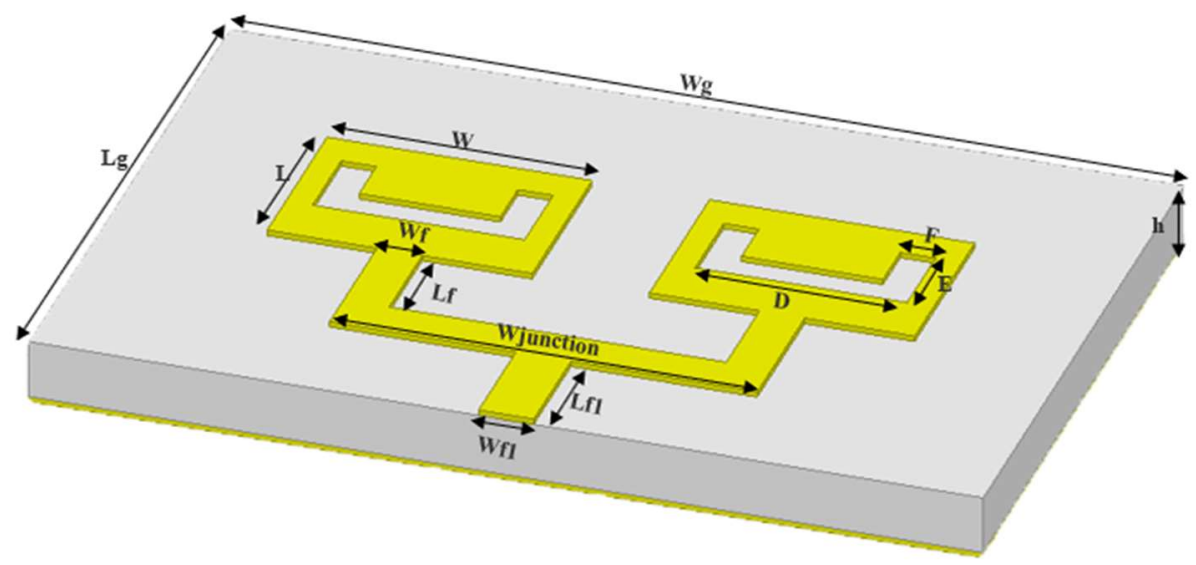

Gambar 6. Desain Antena Mikrostrip Rectangular Patch Array $1 \times 2$ dengan U-Slot.

Pada perancangannya, impedansi yang digunakan pada feeder yang terhubung dengan saluran lossless sebesar $50 \Omega$, sedangkan pada feeder untuk patch sebesar $100 \Omega$. Sebelum dilakukan simulasi, perlu ditambahkan suatu batasan yang berupa ruang hampa. Hal ini dilakukan untuk mengkondisikan simulasi antena sesuai dengan kondisi nyata di lapangan. Ukuran dari ruang hampa yang digunakan pada umumnya $\geq \frac{1}{4} \lambda$ (Ruswanditya, Wijanto, \& Wahyu, 2017).

Tabel 2. Dimensi Antena.

\begin{tabular}{|c|c|c|}
\hline Variabel & Dimensi $(\mathbf{m m})$ & Deskripsi \\
\hline$W g$ & 24,3 & Lebar groundplane \\
\hline$L g$ & 16,198 & Panjang groundplane \\
\hline$W p$ & 6,75 & Lebar patch \\
\hline$L p$ & 4,82 & Panjang patch \\
\hline$L f$ & 2,665 & Panjang feeder $100 \Omega$ \\
\hline$W f$ & 1,15 & Lebar feeder $100 \Omega$ \\
\hline$L f 1$ & 4,15 & Panjang feeder $50 \Omega$ \\
\hline$W f 1$ & 1,4 & Lebar feeder $50 \Omega$ \\
\hline$W j u n c t i o n$ & 10,89 & Lebar T-junction \\
\hline$E$ & 2,3 & Panjang slot vertikal \\
\hline$D$ & 5,4 & Panjang slot horisontal \\
\hline$F$ & 0,9 & Lebar slot \\
\hline$h$ & 1,575 & Tebal substrat \\
\hline
\end{tabular}




\section{HASIL DAN PEMBAHASAN}

Hasil dari simulasi antena yang menggunakan rectangular patch yang disusun secara array $1 \times 2$ dilakukan analisis baik yang menggunakan U-Slot maupun tanpa slot. Parameter yang digunakan untuk dianalisis antara lain nilai return loss $\left(\mathrm{S}_{11}\right)$, bandwidth, nilai axial ratio yang digunakan untuk mengetahui jenis polarisasi, serta gain secara dua dimensi dan tiga dimensi untuk mengetahui pola radiasi.

\subsection{Analisis Perubahan Bandwidth}

Bandwidth merupakan rentang frekuensi yang dibatasi oleh nilai return loss $\left(\mathrm{S}_{11}\right)$ tertentu. Pada penelitian ini batas nilai return loss yang digunakan yaitu kurang dari $-15 \mathrm{~dB}$. Return loss sebuah parameter yang digunakan untuk mengetahui seberapa daya yang hilang akibat pantulan dari saluran transmisi sehingga tidak dapat diradiasikan secara utuh oleh antena. Hasil grafik return loss hasil simulasi dapat dilihat pada Gambar 6.

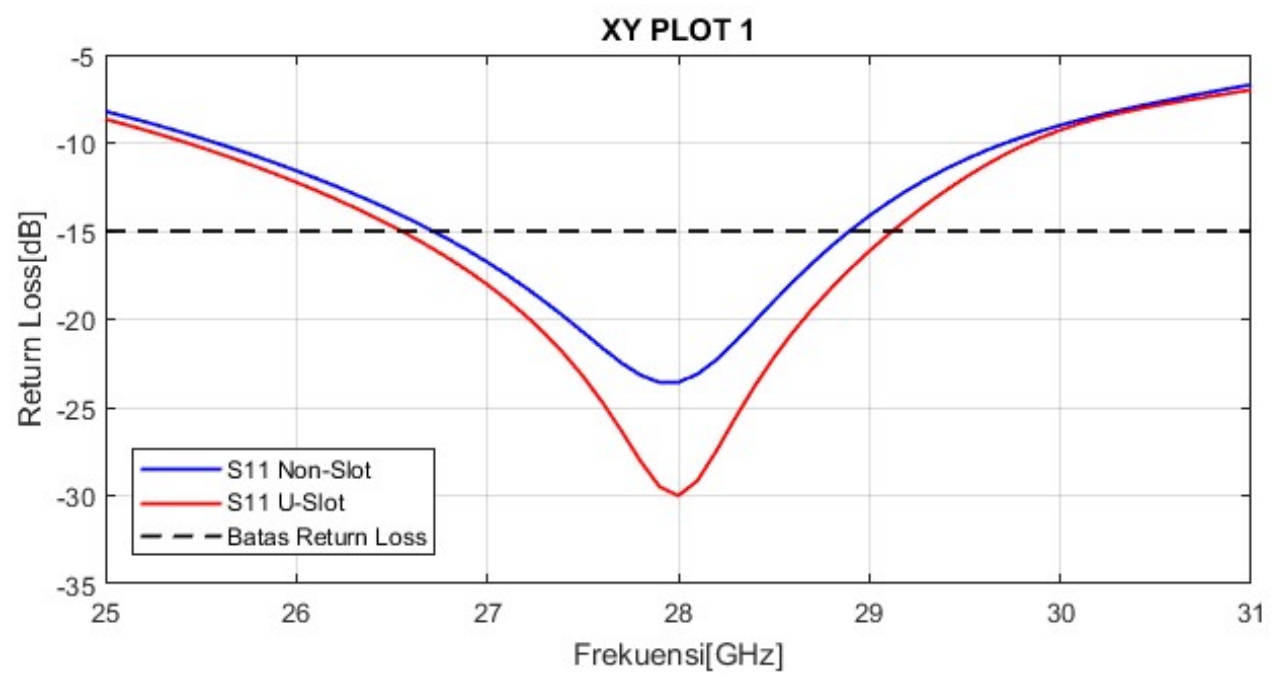

Gambar 6. Hasil Simulasi Return Loss Rectangular Patch Array $1 \times 2$ Non-Slot dan Slot.

Gambar 6 menunjukkan hasil simulasi nilai return loss menggunakan rectangular patch yang disusun secara array $1 \times 2$ baik menggunakan slot maupun tanpa slot. Dari kurva tersebut, didapatkan nilai return loss untuk antena non-slotmencapai nilai di bawah $-15 \mathrm{~dB}$ pada rentang frekuensi 27,5 GHz - 28,89 GHz, sedangkan untuk antena yang menggunakan slot memiliki frekuensi kerja dari $27,5 \mathrm{GHz}-29,12 \mathrm{GHz}$. Hal ini berarti bahwa masih terdapat $380 \mathrm{MHz}$ untuk mencapai frekuensi $29,5 \mathrm{GHz}$. Nilai return loss minimum terjadi pada frekuensi $28 \mathrm{GHz}$ baik yang tanpa slot maupun menggunakan slot dengan nilai $-23,57 \mathrm{~dB}$ dan $-29,38 \mathrm{~dB}$. Hal ini menandakan bahwa antena dapat bekerja pada frekuensi resonansi yang diinginkan, yaitu 28 $\mathrm{GHz}$. Berdasarkan hasil simulasi return loss tersebut, besar bandwidth antena yang tanpa menggunakan slot sebesar $1,39 \mathrm{GHz}$, sedangkan dengan slot sebesar 1,62 GHz. Terjadi peningkatan bandwidth antena sebesar $230 \mathrm{MHz}$ atau sebesar 16,54 \% dari bandwidth awal antena. Dengan demikian antena yang menggunakan slot telah memenuhi spesifikasi bandwidth yang diinginkan. Selain itu, dengan melakukan penambahan slot pada patch antena dapat menurunkan nilai return loss, semakin kecil nilai return loss maka daya yang dipantulkan semakin kecil.

\subsection{Analisis Perubahan Gain}

Gain merupakan nilai perbandingan intensitas daya kearah tertentu terhadap intensitas daya yang didapatkan dari antena referensi yang meradiasikan daya secara isotropis. Pengukuran gain berkaitan dengan seberapa keterarahan antena untuk meradiasikan pada arah tertentu. 
Semakin tinggi gain antena, maka arah radiasi antena semakin terarah ke sudut yang diinginkan. Pada Gambar 7 dan 8 dapat dilihat hasil simulasi nilai gain maksimum antena.

Pada Gambar 7 merupakan hasil simulasi nilai gain antena maksimum secara tiga dimensi menggunakan rectangular patch dengan rectangular patch array $1 \times 2$. Dimana didapat nilai gain maksimum antena rectangular patch sebesar 6,70 dB, sedangkan untuk antena rectangular patch array 1x2 sebesar 7,08 dB. Dengan demikian, dengan melakukan penyusunan antena array dapat meningkatkan gain antena sebesar 1,09 kali. Penggunaan elemen yang semakin banyak dapat menghasilkan gain yang semakin besar (Errifi , Baghdad, Badri, \& Sahel, 2010).
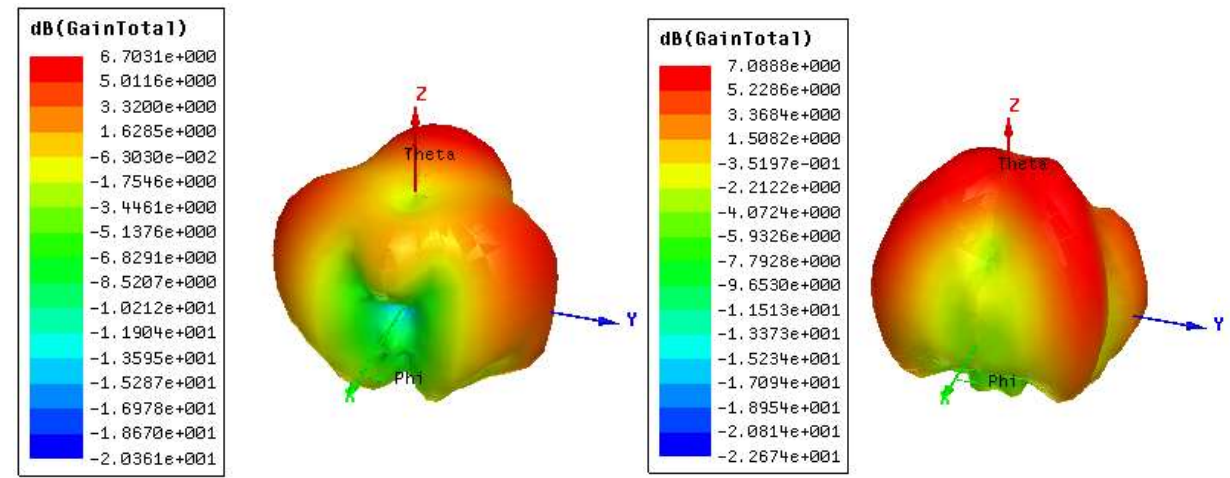

\section{Gambar 7. Hasil Simulasi Gain Rectangular Patch dan dengan Rectangular Patch Array} $1 \times 2$ Non-Slot (kanan).

Gambar 8 menunjukkan hasil simulasi nilai gain maksimum secara tiga dimensi menggunakan rectangular patch yang disusun secara array $1 \times 2$ baik menggunakan slot maupun tanpa slot. Nilai gain maksimum antena tanpa menggunakan slot sebesar 7,08 dB, sedangkan untuk antena yang menggunakan slot sebesar 7,52 dB. Dengan demikian, antena yang dirancang telah sesuai dengan spesifikasi yang telah diharapkan, yaitu lebih dari $7 \mathrm{~dB}$. Selain itu, penambahan slot dapat meningkatkan gain antena sebesar 1,1 kali. Sehingga penyusunan antena menjadi array $1 \times 2$ dengan penambahan U-Slot dapat meningkatkan gain sebesar $20,34 \%$ dari gain antena tanpa array. Hal ini menandakan bahwa antena yang disusun secara array $1 \times 2$ telah memenuhi spesifikasi yang dirancang.
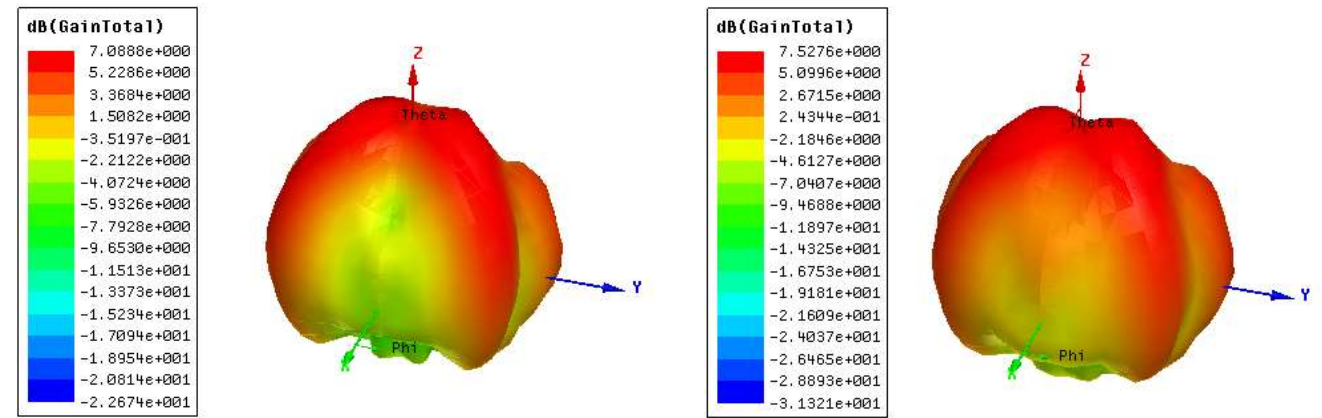

Gambar 8. Hasil Simulasi Gain Rectangular Patch Array $1 \times 2$ Non-Slot (kiri) dan dengan Slot(kanan).

\subsection{Analisis Perubahan Axial Ratio}

Axial ratio merupakan nilai perbandingan antara sumbu mayor dan sumbu minor pada bidang medan listrik suatu antena yang dinyatakan dalam dB. Nilai axial ratio dapat dijadikan acuan untuk menentukan jenis polarisasi suatu antena. Nilai axial ratio yang berada pada rentang 
$3 \mathrm{~dB}-40 \mathrm{~dB}$ menandakan antena memiliki polarisasi ellips, sedangkan jika memiliki nilai axial ratio lebih dari $40 \mathrm{~dB}$ menandakan antena berpolarisasi secara linear. Nilai axial ratio dapat dilihat pada Gambar 9.

Gambar 9 menunjukkan hasil simulasi nilai axial ratio menggunakan rectangular patch yang disusun secara array $1 \times 2$ baik menggunakan slot maupun tanpa slot. Dari kurva tersebut, pada kondisi arah pancar utama yaitu pada $\varphi=0^{\circ}$ (antena mengarah ke depan) didapatkan nilai axial ratio untuk antena tanpa menggunakan slotmemiliki nilai sebesar $48,45 \mathrm{~dB}$ dan nilai terbesar berada pada sudut $30^{\circ}$. Antena yang menggunakan slot pada kondisi arah pancar utama yaitu pada $\varphi=0^{\circ}$ (antena mengarah ke depan) memiliki nilai axial ratio sebesar 40,42 $\mathrm{dB}$ dan nilai terbesar pada sudut $230^{\circ}$. Untuk sudut lainnya memiliki nilai rata-rata axial ratio diatas $40 \mathrm{~dB}$. Berdasarkan hasil simulasi tersebut, maka antena yang dirancang menghasilkan polarisasi linear sesuai dengan spesifikasi yang telah ditentukan. Hal ini dikarenakan antena memiliki nilai axial ratio lebih dari $40 \mathrm{~dB}$ meskipun penambahan slotmenyebabkan penurunan nilai axial ratio suatu antena.
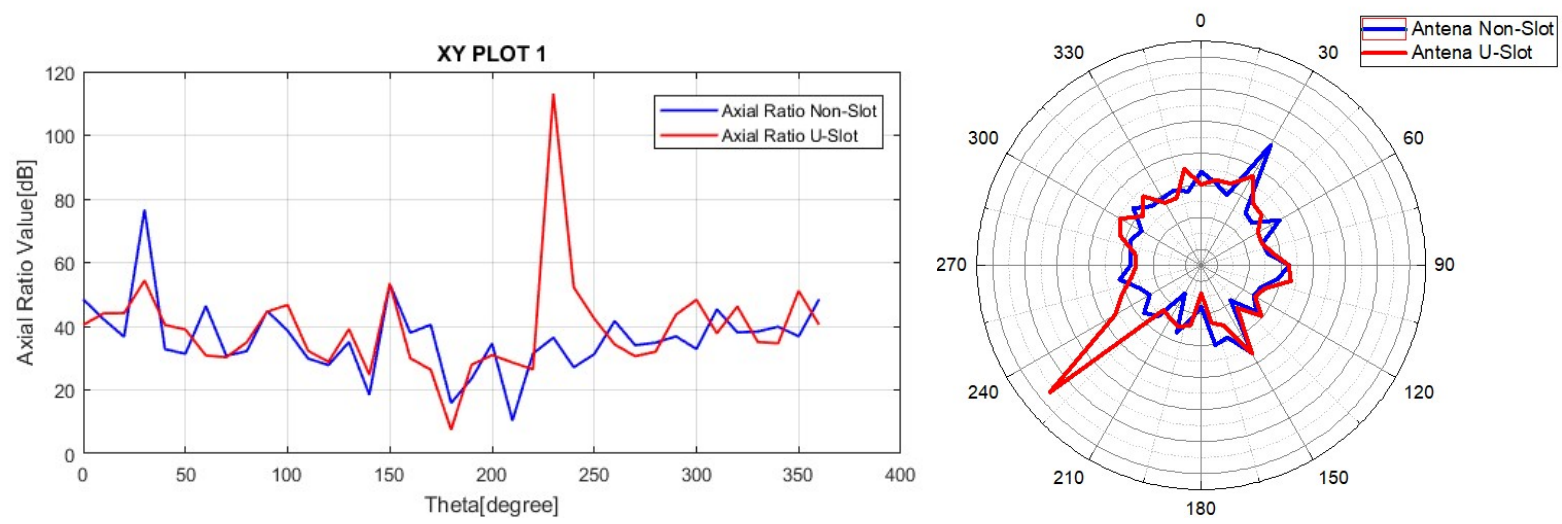

\section{Gambar 9. Hasil Simulasi Nilai Axial Ratio Rectangular Patch Array $1 \times 2$ Non-Slot dan dengan Slot.}

\subsection{Analisis Perubahan Pola Radiasi}

Pola radiasi merupakan bentuk grafis dua dimensi yang menggambarkan sifat pancaran dari antena. Terdapat dua hal dalam peninjauan pola radiasi, yaitu secara elevasi yang direpresentasikan sebagai theta $(\theta)$ dan secara azimuth yang direpresentasikan sebagai phi $(\varphi)$. Pada Gambar 9 dan Gambar 10 dapat dilihat bentuk Pola Radiasi secara dua dimensi.
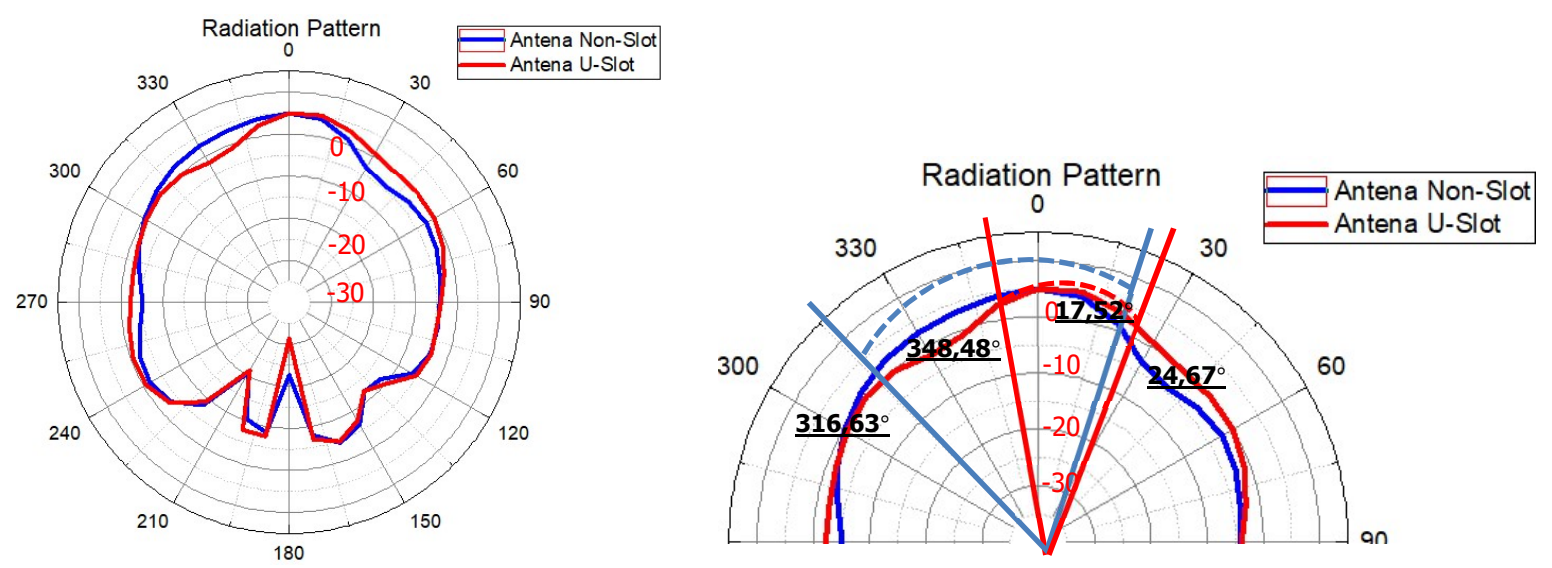

Gambar 10. Hasil Simulasi Pola Radiasi (kiri) dan Perhitungan Lebar Sudut Beamwidth (kanan) Rectangular Patch Array $1 \times 2$ secara Elevasi. 
Gambar 10 dan Gambar 11 menunjukkan pernyataan secara grafis pola radiasi secara dua dimensi antena rectangular patch array $1 \times 2$ yang menggunakan slot dan non-slot. Pada arah elevasi antena yang menggunakan slotmaupun non-slotmemiliki arah pancar maksimum pada sudut $10^{\circ}$ dan $0^{\circ}$, sedangkan untuk arah azimuth pada sudut $-20^{\circ}$ baik menggunakan slot maupun non-slot. Sehingga, dari arah elevasi maupun azimuth antena memiliki pola radiasi secara unidireksional, hal ini juga dibuktikan dengan arah pancar lebih dominan ke arah atas (sumbu positif). Selain itu, penambahan slot tidak terlalu berpengaruh pada perubahan pola radiasi antena. Meski demikian, antena yang dirancang dapat memenuhi spesifikasi pola radiasi antena, yaitu unidireksional.
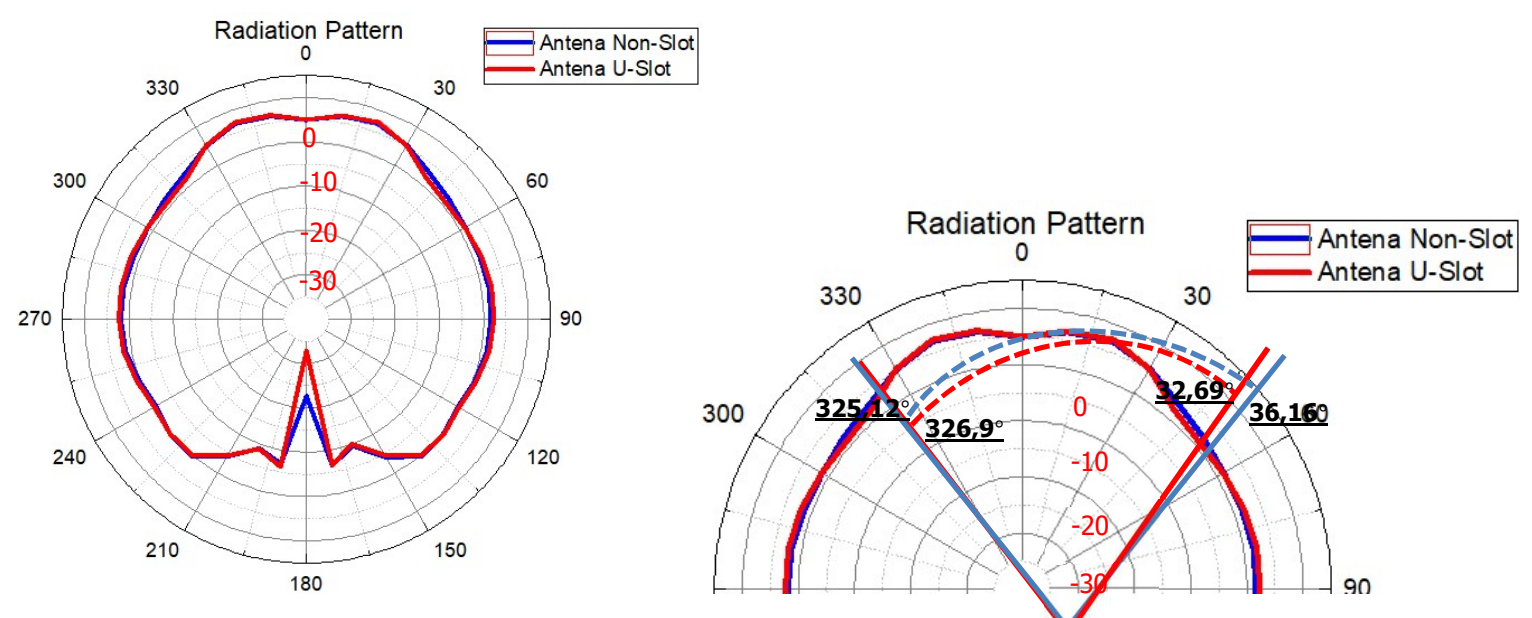

Gambar 11. Hasil Simulasi Pola Radiasi (kiri) dan Perhitungan Lebar Sudut Beamwidth (kanan) Rectangular Patch Array $1 \times 2$ secara Azimuth.

Tabel 3 menunjukkan perubahan nilai HPBW suatu antena. HPBW atau Half Power Beamwidth. Beamwidth merupakan lebar berkas pola radiasi pada main lobe yang dinyatakan dalam derajat. Pengukuran HPBW meninjau beamwidth dengan pengurangan daya sebesar $3 \mathrm{~dB}$ terhadap peak gain dari antena. Dari tabel tersebut, menunjukkan hasil simulasi nilai HPBW secara elevasi dan azimuth pada antena rectangular patch array $1 \times 2$ yang menggunakan slot dan non-slot. Nilai HPBW antena tanpa menggunakan slot dan dengan slot pada arah elevasi sebesar $60,89^{\circ}$ dan $36,1^{\circ}$, sedangkan pada arah azimuth sebesar $71,04^{\circ}$ dan $65,79^{\circ}$. Dengan demikian, penambahan slotyang berbentuk huruf $U$ dapat mengurangi nilai HPBW antena baik secara elevasi maupun azimuth.

Tabel 3. Perubahan Nilai HPBW Antena.

\begin{tabular}{|c|c|c|}
\hline \multirow{2}{*}{ Parameter } & \multicolumn{2}{|c|}{ Jenis Antena } \\
\cline { 2 - 3 } & Tanpa Slot & Dengan U-Slot \\
\hline HPBW Elevasi & $60,89^{\circ}$ & $36,19^{\circ}$ \\
\hline HPBW Azimuth & $71,04^{\circ}$ & $65,79^{\circ}$ \\
\hline
\end{tabular}

\subsection{Analisis Kinerja Simulasi}

Perbandingan hasil simulasi parameter antena pada frekuensi $28 \mathrm{GHz}$ menggunakan slot dan tanpa slot serta spesifikasi antena yang dirancang dapat dilihat pada Tabel 4. Perancangan antena dengan penambahan slotyang berbentuk huruf $U$ pada patch antena berdampak pada peningkatan bandwidth antena hingga $230 \mathrm{MHz}$ serta menurunkan nilai return loss pada antena dan meningkatkan gain antena. Antena yang dirancang telah memenuhi spesifikasi yang diharapkan yaitu $27,5 \mathrm{GHz}-29,1 \mathrm{GHz}$ dengan gain $\geq 7 \mathrm{~dB}$ dan memiliki pola radiasi unidireksional. 
Tabel 4. Perbandingan Hasil Simulasi Kinerja Antena.

\begin{tabular}{|c|c|c|c|}
\hline Parameter & Spesifikasi & Tanpa Slot & Dengan U-Slot \\
\hline Frekuensi Resonansi & $28 \mathrm{GHz}$ & $28 \mathrm{GHz}$ & $28 \mathrm{GHz}$ \\
\hline Rentang Frekuensi & $27,5 \mathrm{GHz}-29,1 \mathrm{GHz}$ & $27,5 \mathrm{GHz}-28,89 \mathrm{GHz}$ & $27,5 \mathrm{GHz}-29,12 \mathrm{GHz}$ \\
\hline Return Loss & $<-15 \mathrm{~dB}$ & $-23,57 \mathrm{~dB}$ & $-29,38 \mathrm{~dB}$ \\
\hline Bandwidth & $1,6 \mathrm{GHz}$ & $1,39 \mathrm{GHz}$ & $1,62 \mathrm{GHz}$ \\
\hline Gain Maximum & $\geq 7 \mathrm{~dB}$ & $7,08 \mathrm{~dB}$ & $7,52 \mathrm{~dB}$ \\
\hline Axial Ratio & $>40 \mathrm{~dB}$ & $48,45 \mathrm{~dB}$ & $40,42 \mathrm{~dB}$ \\
\hline Polarisasi & Linear & Linear & Linear \\
\hline Polaradiasi & Unidireksional & Unidireksional & Unidireksional \\
\hline
\end{tabular}

\section{KESIMPULAN}

Pengujian dan analisis simulasi antena mikrostrip rectangular patch array $1 \times 2$ pada frekuensi $28 \mathrm{GHz}$ telah dilakukan. Hasil dari simulasi menunjukkan bahwa antena dengan penambahan slot yang berbentuk $\mathrm{U}$ dapat menghasilkan nilai return loss sebesar $-29,38 \mathrm{~dB}$, sehingga terjadi peningkatan bandwidth antena sebesar $230 \mathrm{MHz}$ atau 16,54\% dari bandwidth antena awal. Gain maksimum yang dihasilkan memenuhi spesifikasi, yaitu sebesar 7,52 dB. Penambahan slot dapat meningkatkan gain antena sebesar 20,34\%. Pola radiasi yang dihasilkan baik secara elevasi maupun azimuth, yaitu unidireksional. Penambahan slot dapat menurunkan derajat HPBW. Polarisasi yang dihasilkan, yaitu polarisasi linear dengan nilai axial ratio lebih dari 40 $\mathrm{dB}$. Penambahan slotdapat menurunkan nilai axial ratio suatu antena. Selain itu, hasil simulasi menunjukkan bahwa antena yang dirancang berpotensi untuk digunakan pada teknologi 5G, karena telah memenuhi standar yang direkomendasikan. Langkah kedepaanya, akan dilakukan pengukuran terhadap antena yang telah dirancang.

\section{DAFTAR RUJUKAN}

5 G Americas White Paper on 5 G Spectrum Recomendations. (2017). 5G Americas.

Ardianto, F. W., Adriansyah, N. M., \& Syihabuddin, B. (2018). Analisis Simulasi Antena MIMO 44 Susunan Persegi dan Sirkular pada Frekuensi 15 GHz. Jurnal Nasional Teknik Elektro dan Teknologi Informasi, 174-182.

Ather, S. N., \& Singhal, P. K. (2013). Truncated Rectangular Microstrip Antenna with $\mathrm{H}$ and U Slot for Broadband. International Journal of Engineering Science and Technology (IJEST), 114-118.

Balanis, C. A. (2005). Antena Theory Analysis and Design 3nd Edition. USA: Wiley Interscience. Errifi , H., Baghdad, A., Badri, A., \& Sahel, A. (2010). Design and Simulation of Microstrip Patch Array Antenna with High Directivity for $10 \mathrm{GHz}$ Applications. International Symposium on Signal Image Video and Communications (hal. 19-21). Marrakech, Maroc: ISIVC. 
Firmansyah, T., Purnomo, S., Fatonah, F., \& Nugroho, T. H. (2015). Antena Mikrostrip Rectangular Patch 1575,42 MHz dengan Polarisasi Circular untuk Receiver GPS. Jurnal Nasional Teknik Elektro dan Teknologi Informasi (JNTETI), 2301 - 4156.

Hakimi, S., \& Rahim, S. K. (2014). Millimeter-wave microstrip Bent line Grid Array antenna for 5 G mobile communication networks. Asia-Pacific Microwave Conference (APMC) (hal. 622 - 624). Japan: IEEE.

Kakkar, A., Nirdosh, Tripathy, M. R., \& Singh, A. K. (2017). Design and Analysis of Slotted Antenna Array for 5G Application. Progress In Electromagnetics Research Symposium - Fall (PIERS - FALL) (hal. 459-463). Singapore, Singapore: IEEE.

Prabhu, V. S., Archana, R., Mercy, A. M., \& Sree, G. B. (2017). Design and Simulation of Single patch and Linear Array (1x3) for Smart Antenna Applications. International Journal of Electronics and Communication Engineering, 208-212.

Qamar, F., Siddiqui, M. H., Dimyati, K., Noordin, K. A., \& Majed, M. B. (2017). Channel Characterization of 28 and $38 \mathrm{GHz}$ MMWave Frequency Band Spectrum for the Future 5G. IEEE 15th Student Conference on Research and Development (SCOReD) (hal. 291296). Putrajaya, Malaysia: IEEE.

Ruswanditya, A. S., Wijanto, H., \& Wahyu, Y. (2017). Mimo 8x8 Antenna with Two H-Slotted rectangular patch array for $5 \mathrm{G}$ access radio at $15 \mathrm{GHz}$. International Conference on Control, Electronics, Renewable Energy and Communications (ICCREC) (hal. 221 226). Yogyakarta, Indonesia: IEEE.

Sinaga, K. J., Nur, L. O., \& Syihabuddin, B. (2017). Perancangan Antena Array $1 \times 2$ Rectangular Patch Dengan U-Slot Untuk Aplikasi 5G. Seminar Nasional Inovasi Dan Aplikasi Teknologi Di Industri 2017, (hal. B34.1 - B34.9). Malang.

Singh, I., \& Tripathi, V. (2011). Micro strip Patch Antenna and its Applications: a Survey. International Journal of Computer Techonlogy and Applications, 1595-1599.

Tateishi, K., Kurita, D., Harada, A., Kishiyama, Y., Itoh, S., Murai, H., . . Ökvist, P. (2017). Experimental Evaluation on 5G Radio Access Employing Multi-user MIMO at $15 \mathrm{GHz}$ Band. 14th IEEE Annual Consumer Communications \& Networking Conference (CCNC) (hal. 951 - 956). Las Vegas: IEEE.

Wiyanto, E., Alam, S., \& Harsono, B. (2018). Realisasi dan Pengujian Antena Mikrostrip Array 4 Elemen dengan Polarisasi Melingkar untuk Aplikasi 4G/LTE. ELKOMIKA: Jurnal Teknik Energi Elektrik, Teknik Telekomunikasi, \& Teknik Elektronika, 244-258. 